\title{
Calibration and Validation of CERES-Maize Model for Hybrid Maize under Variable Plant Densities and Nitrogen Levels in Southern Telangana Zone of Telangana State, India
}

\author{
P. Leela Rani ${ }^{1 *}$, G. Sreenivas ${ }^{2}$ and D. Raji Reddy ${ }^{3}$ \\ ${ }^{1}$ AICRP on Weed Management, College of Agriculture, ${ }^{2}$ Agro Climate Research Centre, Agriculture Research Institute, \\ ${ }^{3}$ Director of Research, Professor Jayashankar Telangana State Agricultural University, \\ Rajendranagar, Hyderabad (500 030), India
}

Article History

Manuscript No. AR1533

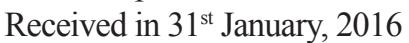

Received in revised form $6^{\text {th }}$ February, 2016

Accepted in final form $6^{\text {th }}$ April, 2016

Correspondence to

"E-mail: leelagro@gmail.com

Keywords

CERES-Maize, calibration, validation, nitrogen levels, planting dates

\begin{abstract}
CERES-Maizemodel (DSSAT v 4.5) was calibrated and validated for maize hybrid (cv Dekalb Super 900M) using experimental data obtained from different dates of sowing and nitrogen levels (7-July, 21-July, 6-August and 22 August in 2009 and 18 June, 02 July, $17^{\text {th }}$ July and $02^{\text {nd }}$ August in 2010 and $0 \mathrm{~kg} \mathrm{ha}^{-1}$ control; $100 \mathrm{~kg} \mathrm{ha}^{-1} ; 200$ $\mathrm{kg} \mathrm{ha}^{-1} ; 300 \mathrm{~kg} \mathrm{ha}^{-1}$ and $400 \mathrm{~kg} \mathrm{ha}^{-1}$ ) at Agricultural Research Institute, Rajendranagar, Hyderabad, India. Calibration analysis revealed that the model provided satisfactory estimates for the phenology, grain yield and total biomasswith RMSE of 0.87 days, 363 and $412 \mathrm{~kg} \mathrm{ha}^{-1}$, respectively. Calibrated model used for further validation with experimental data and found that,simulation of phenology and physiological maturity wasconsidered as excellent with NRMSE value being less than $10 \%$. Whereas, simulation of LAI, number of grains per cob, grains $\mathrm{m}^{-2}$, grain yield and stover yield was considered as good with simulation values ranging in between 10.1 to $20 \%$. But the simulation of nitrogen content of biomass was poor as the simulation of total biomass was poor as the NRMSE value is more than $20.1 \%$. So Validated CERESMaize model can be used as a research tool under irrigated conditions up to $21^{\text {st }} \mathrm{July}$ sowings to take strategic decision for improving maize production in different agro climatic zones of Telangana State.
\end{abstract}

\section{Introduction}

Farmers need to make informal decisionsin order to plan and manage their farms efficiently. Strategic and tactical decisions such as when to plant, what cultivar to use, when and in what manner to fertilize and irrigate and when to harvest are frequently made based on rules-of-thumb, years of grow erexperience and advice from agricultural consultants. In the $21^{\text {st }}$ century information needed for agricultural decision making at all the levels are increasing rapidly due to increased demands for agricultural products and increased pressures on land, water and other natural resources as a result of climate related risks and rapid changes in technology. This challenge becomes increasingly difficult to manage as farming operations increase in size and complexity. Reliable and timely prediction of crop yield is important for decision and policy making on agriculture. Traditionally agronomic experiments are conducted at particular points in time, space, making results site and season-specific, time consuming and expensive. Recently, in addition to profitable crop production, the quality of the environment has become an important issue that agricultural producers must address. In his annual presidential address to the Royal Meteorological Society, Monteith (1981) said "The statistical blunderbuss is a very clumsy weapon for attacking the problem of crop-weather relations; but it is also very uninstructive because it ignores the interaction of physical and physiological mechanisms". Field experiments to capture all the multi year and multi location variability are nearly impossible. So there is a need to integrate knowledge between the crop and its outside side environment (soil and weather) and management practices for making better decisions inorder to transfer production technology from one location to other locations, where soils and climate are differed. This can be possible only through Knowledge-based Systems Approach. Knowledge-based systems are computer systems (models) that are programmed to imitate the human problem solving ability by means of artificial intelligence (AI) tools. Systems approach makes use of dynamic simulation of crop growth and of cropping systems through models.

Under these circumstances, Decision Support System for Agrotechnology Transfer (DSSAT) has been proved to 
be one of such valuable tool for making viable decisions on management practices for different crops in relation to soil water nutrient dynamics during and after the crop growing season and their transfer to any point in space and time (Jones et al., 2003). CERES-Maize model a part of DSSAT is one of the widely used, among the models that exist (Jones and Kiniry, 1986; Jones et al., 2003). The validated model could be used to simulate crop yield and other output variables reliably in different environments (Singh, 1989).

The CERES-Maize model has been extensively tested under tropical conditions of Hawaii, Indonesia and Phillippines (Singh, 1985) USA and Europe (Jones and Kiniry, 1986; Bannuayen et al. 2003), Kenya (Keating et al., 1991) and India (Reddy, 1991; Shekh and Rao, 1996). CERES-Maize model used in Nigeria for evaluating the performance of different duration varieties and found that, short duration varieties performed better than long duration varieties and the risk of crop failure at three sites would be high if nitrogen is not applied (Jagtap et al., 1999). Under Indian conditions, Karthikeyan and Balasubramaniyan (2005) reported that the date of tasseling and grain yield predicted by CERES-Maize model showed good agreement with the observed values. But the model poorly predicted the biomass yield and harvest index of maize. Singh et al. (2010) reported 23.8\% error in simulated yield when compared with observed stalk yield during Kharif season in Uttar Pradesh, whereas CERES-Maize model indicated its ability to simulate maize dry matter accumulation under optimal growth conditions and it was confirmed that this model consistently under predicted biomass yield by 10 to $20 \%$ (Yang et al., 2004).

However, the CERES-Maize model has not been used and evaluated under different agro climatic conditions of Telangana State. Keeping the above points in view, the present study was carried out to evaluate the CERES-Maize model in Southern Telanagana Agro climatic Zone of Telangana State to take strategic decisions since the area under maize is increasing every year due to introduction of high yielding single cross hybrids coupled with high input management.

\section{Materials and Methods}

CERES-Maize model was validated with the data sets generated during kharif 2009 and 2010 through the field experiments, laid out in split plot design with three replications on sandy loam soil of the Agriculture Research Institute, Rajendranagar, Hyderabad. The treatments comprised of four dates of sowing ( $7^{\text {th }}$ July, $21^{\text {st }}$ July, $6^{\text {th }}$ August and $22^{\text {nd }}$ August in 2009 and $18^{\text {th }}$ June, $02^{\text {nd }}$ July, $17^{\text {th }}$ July and $02^{\text {nd }}$ August in 2010) as main plots and five nitrogen levels $\left(\mathrm{N}_{0}\right.$ : Control; $\mathrm{N}_{1}: 100 \mathrm{~kg} \mathrm{ha}^{-1} ; \mathrm{N}_{2}: 200$ $\mathrm{kg} \mathrm{ha}^{-1} ; \mathrm{N}_{3}: 300 \mathrm{~kg} \mathrm{ha}^{-1}$ and $\mathrm{N}_{4}: 400 \mathrm{~kg} \mathrm{ha}^{-1}$ ) as sub-plots. The cultivar used for the study was Dekalb Super 900M. Crop was fertilized with uniform dose of $60 \mathrm{~kg} \mathrm{P}_{2} \mathrm{O}_{5}, 40 \mathrm{~K}_{2} \mathrm{O}$ and $50 \mathrm{~kg}$ $\mathrm{ZnSO}_{4} \mathrm{~kg} \mathrm{ha}^{-1}$. One third of the total $\mathrm{N}$ and full $\mathrm{P}, \mathrm{K}$ and $\mathrm{ZnSO}_{4}$ were applied at the time of sowing as basal. Remaining $\mathrm{N}$ was applied in two equal splits at knee high stage (30 DAS) and at tasseling stage. Other cultural operations and plant protection measures were followed as per the recommended package of practices. The weather data during experimental period was recorded from the meteorological observatory located at Agricultural Research Institute, Rajendranagar, Hyderabad.

It is necessary to calibrate the model for further use with crop cultivars and soils of the target regions and also to evaluate the accuracy of the model calculations. The CERES-Maize model was calibrated with the data obtained from the 2007 and 2008 field experiments under different planting dates with uniform dose of $200 \mathrm{~kg} \mathrm{~N} \mathrm{ha}^{-1}$ as it had the best performance. CERESMaize model requires a set of six eco-physiological coefficients for simulation of phenology, growth and grain yield of cultivar. The cultivar coefficients were determined sequentially, starting with phenological parameters followed by the grain filling parameters and finally total biomass and grain yield (Hunt and Boote, 1998). Since such data was not available, the genetic coefficients of Dekalb Super 900M were estimated by repeated iterations as suggested by Hunt et al. (1993) until a close match obtained between simulated and observed phenology, growth and yield. A detailed description of the cultivar coefficients used by the CERES-Maize model was presented in Table 1 . After the calibration of the cultivar coefficients, accuracy of the model simulations and performance of genetic coefficients were assessed by running model with independent data sets collected during the year of 2009 and 2010 against nitrogen treatments under variable weather conditions.

Statistical based criteria provide a more objective method for evaluation of the performance of the models (Ducheyne, 2000). Simulation performance was evaluated with different test statistics like root mean square error (RMSE) (Wallach and Goffinet, 1989). These measurements were calculated as

RMSE $=\left[\sum_{i=1}^{n}\left(p_{i}-o_{i}\right)^{2} / n\right]^{0.5}$

Where $\mathrm{P}_{\mathrm{i}}$ and $\mathrm{O}_{\mathrm{i}}$ are the predicted and observed values for studied variables, respectively and $\mathrm{n}$ is the number of observations. Model performance improved as RMSE, MPD and error proceed to zero. A smaller RMSE indicated less deviation of the simulated from the observed values. Normalized RMSE (NRMSE) gives a measure (\%) of the relative difference between simulated and observed data. The simulation is considered excellent with a normalized RMSE less than $10 \%$, good if the normalized RMSE is greater than 10 
Table 1: Genetic coefficients of Dekalb Super $900 \mathrm{~m}$ used for CERES-Maize model

\begin{tabular}{|c|c|c|}
\hline Sl. no. & description of coefficients & value \\
\hline 1. & $\begin{array}{l}\mathrm{P}_{1} \text { : Thermal time from seedling emergence to the end of the juvenile phase (expressed in growing degree days } \\
\text { above a base temperature of } 8^{\circ} \mathrm{C} \text { ) during which plant is not responsive to changes in photoperiod. }\end{array}$ & 250 \\
\hline 2. & $\begin{array}{l}\mathrm{P}_{2}: \text { Extent to which development (expressed as days) is delayed for each hour increase in photoperiod at which } \\
\text { development proceeds at a maximum rate (which is considered to be } 12.5 \text { hours). }\end{array}$ & 0.8 \\
\hline 3. & $\mathrm{P}_{5}:$ Thermal time from silking to physiological maturity (expressed in degree days above a base temperature of $8^{\circ} \mathrm{C}$ ). & 950 \\
\hline 4. & $\mathrm{G}_{2}:$ Maximum possible number of kernels plant ${ }^{-1}$ & 820 \\
\hline 5. & $\mathrm{G}_{3}$ : Kernel filling rate during the linear grain filling stage under optimum conditions (mg day ${ }^{-1}$ ). & 7.4 \\
\hline 6. & PHINT (Phylochron interval): The interval in thermal time (degree days) between successive leaf tip appearances & 50 \\
\hline
\end{tabular}

and less than $20 \%$, fair if the normalized RMSE is greater than $20 \%$ and less than $30 \%$, and poor if the normalized RMSE is greater than 30\% (Loague and Green, 1991). The NRMSE was calculated using the following equation.

Normalized root mean square error $=\left[\frac{\mathrm{RMSE}}{\bar{O}}\right] \times 100$

\section{Results and Discussion}

\subsection{CERES-Maize model calibration}

Calibration results revealed that model predicted only one day difference between observed and simulated days to flowering for hybrid Dekalb Super 900M with RMSE of 0.5 day and MPD value of -0.4 across different sowing dates. CERESMaize model simulated same number of days from planting to physiological maturity with RMSE of 0.9 day and MPD of 0.2 .

Good agreement was noticed between observed and simulated grain yield with RMSE of $363 \mathrm{~kg} \mathrm{ha}^{-1}$. The value of MPD was -0.8. The simulation of total crop biomass at harvest was also well predictedwith RMSE of $411 \mathrm{~kg} \mathrm{ha}^{-1}$ with MPD value of -1.9. Higher values of d-index showed more accurate simulation of crop biomass. In all the cases, the $\mathrm{r}^{2}$ values were $>0.7$ (Table 2).

\subsection{CERES-Maize model validation}

To check the accuracy of model simulations, it was validated with data obtained fromfour dates of sowing and five nitrogen levels during the year 2009 and 2010 respectively. During all this process available data on phenology, leaf area index, total biomass, grain yield andbiomass nitrogen uptake was compared with model simulated values.

\subsubsection{Days to silking}

Simulated values of days to silking of CERES-Maize model was very closer to the observed data, with RMSE value of 1.17 day and NRMSE value of 1.97 respectively, showed the excellent simulation with CERES-Maize model (Figure1). CERES-Maize model did not consider the effect of $\mathrm{N}$ availability on silking by predicting same number of days at all nitrogen levels. This confirms the findings of Pereira et al., (2010), who reported that CERES-Maize model proved very efficient to simulate the flowering and physiological maturity

Table 2: Observed and predicted phenology, yield attributes, grain yield, stover yield and total biomass after calibration of CERES-Maize model

\begin{tabular}{lcccccc}
\hline variable name & $\begin{array}{c}\text { ob- } \\
\text { served }\end{array}$ & $\begin{array}{c}\text { simu- } \\
\text { lated }\end{array}$ & $\mathrm{r}^{2}$ & $\mathrm{mpd}$ & $\mathrm{rmse}$ & $\begin{array}{c}\mathrm{d}- \\
\text { stat. }\end{array}$ \\
\hline $\begin{array}{l}\text { Silking (days) } \\
\text { Maturity (days) }\end{array}$ & 110 & 110 & 0.7 & -0.2 & 0.9 & 0.9 \\
$\begin{array}{l}\text { Total biomass } \\
\left(\mathrm{kg} \mathrm{ha}^{-1}\right)\end{array}$ & 16091 & 16404 & 0.9 & -1.9 & 411.9 & 0.9 \\
$\begin{array}{l}\text { Grain yield } \\
\text { kg ha }^{-1} \text { ) }\end{array}$ & 8114 & 8164 & 0.7 & -0.8 & 363.0 & 0.9 \\
$\begin{array}{l}\text { Stover yield } \\
\left(\mathrm{kg} \mathrm{ha}^{-1}\right)\end{array}$ & 7977 & 8299 & 0.9 & -4.0 & 359.2 & 0.9 \\
$\begin{array}{l}\text { Number of grains } \\
\text { cob }\end{array}$ & 448 & 450 & 0.9 & -0.2 & 27.2 & 0.8 \\
$\begin{array}{l}\text { Numberof grains } \\
\mathrm{m}^{-2}\end{array}$ & 2731 & 2698 & 0.8 & 1.4 & 168.2 & 0.8 \\
$\begin{array}{l}\text { Single grain } \\
\text { weight (g) }\end{array}$ & 0.3 & 0.3 & 0.8 & 0.0 & 0.0 & 0.9 \\
\hline
\end{tabular}

Note: Data of 2007 and 2008 were used for calibration of model

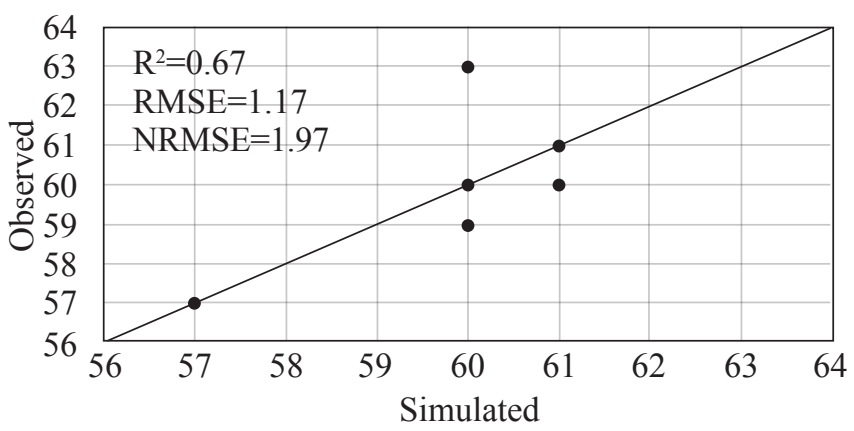

Figure 1: Observed and simulated days to Silking in maize using CERES-Maize model across different dates of sowing sowing and nitrogen levels 
dates as the RMSE values were below $10 \%$, under tropical conditions.

\subsubsection{Days to physiological maturity}

A perfect match was noticed between the observed and simulated values for days to physiological maturity (Figure 2) with RMSE, NRMSE values of 0.7 days and $0.6 \%$ respectively, with excellent simulation as the NRMSE value is being less than $10 \%$. The DSSAT model failed to account for the rapid growth considered as excellent with NRMSE value of $6 \%$ with closelyoptimized by the $\mathrm{N}$ and thus assumed one maturity date for all related treatment.

\subsubsection{Leaf area index (LAI)}

At silking stage, the observed maximum leaf area index across different sowing dates and nitrogen levels was considered good as the NRMSE value was $10.3 \%$ with RMSE value of 0.24 (Figure 3). In similar way Saseendran et al. (2005) found that the RMSEs of LAI simulated by CERES-Maize were between 0.30 and 0.80 across all the planting dates.

\subsubsection{Total biomass}

The CERES-Maize model over predicted the total biomass in the range between -2 to $-40 \%$ with delay in sowing. The simulation of total biomass was considered as poor as there was more difference between simulated and observed total biomass with RMSE and NRMSE values of $2570 \mathrm{~kg}$ and 22.6 respectively (Figure 4). Differences in biomass accumulation among dates were attributed due to differences in observed LAI, which might have intercepted varied amount of solar radiation. Maize simulation models that rely on RUE for biomass accumulation should use an RUE of $3.8 \mathrm{~g} \mathrm{MJ}^{-1}$ APAR for predicting optimum yields without growth limitations. Therefore, it may be expected that these models, as currently parameterized, will not perform well when simulating maize productivity under delayed sowing.

\subsubsection{Grains $\mathrm{cob}^{-1}$}

In similar way simulation of grains $\operatorname{cob}^{-1}$ using experimental data was considered as good with RMSE and NRMSE values of 61 grains and $17.2 \%$ respectively across different dates of sowing and nitrogen levels (Figure 5).

\subsubsection{Grain yield}

Grain yield of early sown crop during both the years of study was in good agreement with simulated grain yield of CERESMaize model except under delayed sowing beyond 17 July (Figure 6). Simulated grain yield was closely related to the observed grain yield with good simulation as the NRMSE value was $14.6 \%$ with RMSE value of $902.8 \mathrm{~kg}$. Reduction in grain yield with delay in planting date as measured in the field was not well reflected in the simulations by CERES-Maize model. However, CERES-Maize was able to capture the relative

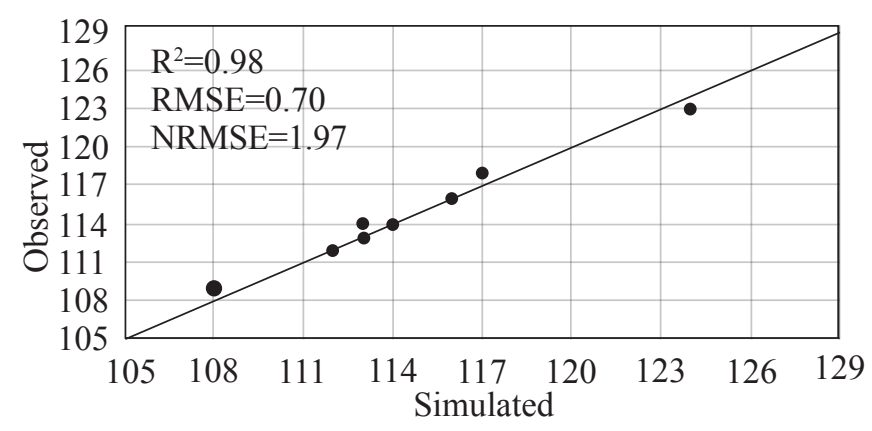

Figure 2: Observed and simulated days to physiological maturity in maize using CERES-Maize model across different dates of sowing and and nitrogen

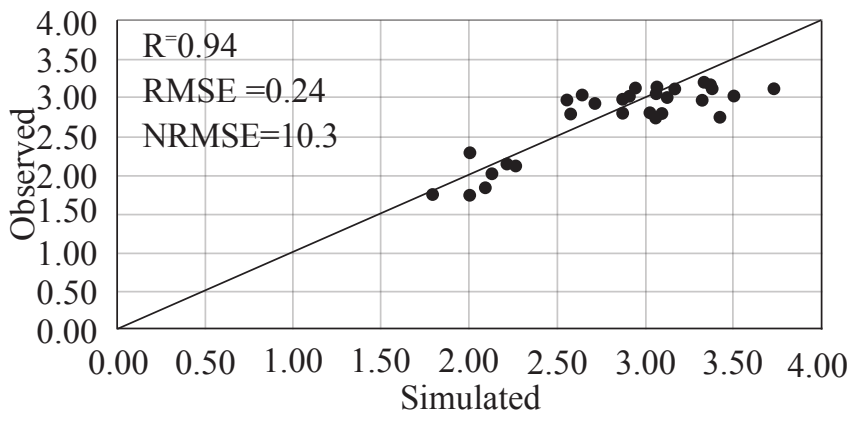

Figure 3: Observed and simulated LAI at silking stage in maize using CERES-Maize model across different dates of sowing and nitrogen levels

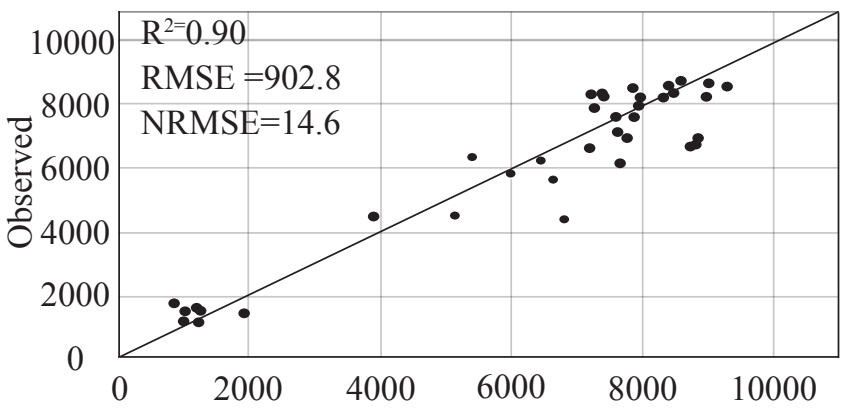

Figure 4: Observed and simulated grain yield $0\left(\mathrm{~kg} \mathrm{ha}^{-1}\right)$ of maize using CERES-Maize model across different dates of sowing and nitrogen levels

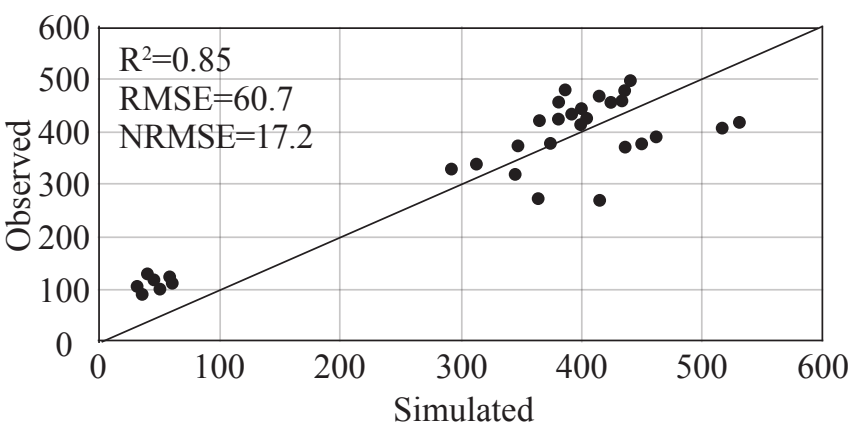

Figure 5: Observed and simulated number of grains cob-1 in maize using CERES-Maize model across different dates of sowing and nitrogen levels 
decrease in grain yield between the first and fourth planting dates with a better level of accuracy. These results do indicate that CERES-Maize model is an adequate tool to simulate maize growth, particularly to evaluate relative changes in crop yield in relation to planting date up to third week of July under local conditions. Saseendran (2005) also reported the similar results for three corn hybrids.

\subsubsection{Nitrogen uptake by biomass}

The simulation scenarios for nitrogen uptake by biomass between observed and simulated values was poor with NRMSE value of $27.9 \%$ with RMSE value of $29.4 \mathrm{~kg}$ across different dates of sowing nitrogen levels (Figure 7).

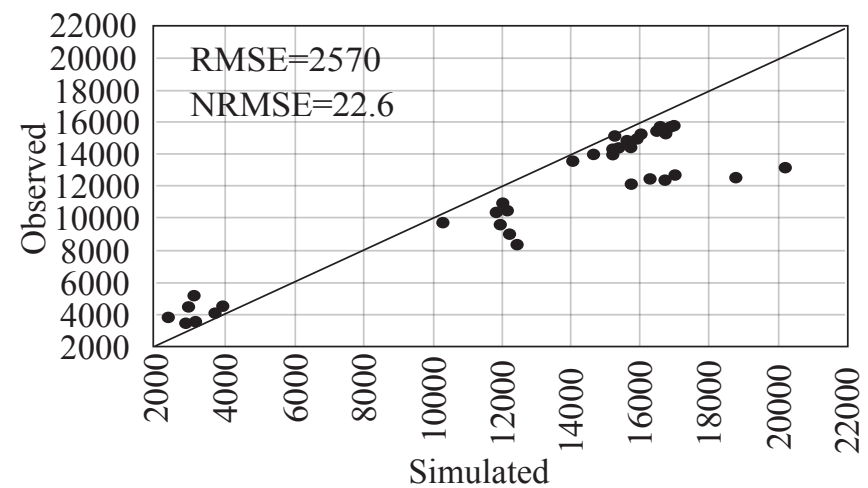

Figure 6: Observed and simulated total biomass of maize using CERES-Maize model across different dates ofsowing and nitrogen levels

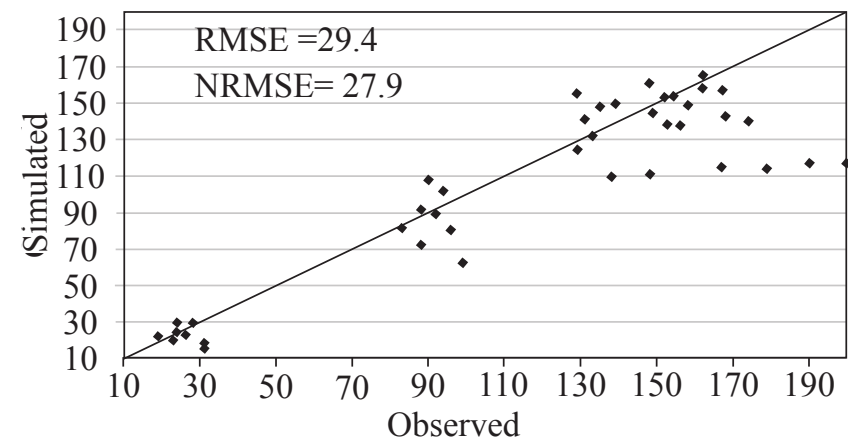

Figure 7: Observed and simulated Nitrogen uptake by biomass using CERES-Maize model across different dates of sowing and nitrogen levels

\section{Conclusion}

Calibrated genetic coefficients for the maize hybrid Dekalb Super $900 \mathrm{M}$ for simulated development and growth parameters were in good agreement with their respective observed data from experiments conducted in Rajendranagar, Hyderabad, Telangana State. Validated CERES-Maize model can be used as a research tool under irrigated conditions up to $21^{\text {st }}$ July sowings to guide alternate ways of improving maize production in different agro climatic zones of Telangana state.

\section{Further Research}

It suggested that in order to be able to identify the optimum management practices for a specific region and for a specific crop, a few years of actual field experiments should be conducted for model evaluation and that long-term historical weather records be used for management scenario analysis.

\section{References}

Bannuayen, M., Crout, N.M.J., Hoogenboom, G., 2003. Application of the CERES-Wheat model for withinseason prediction of winter wheat yield in the United Kingdom Agronomy Journal 95, 114-125.

Ducheyne, S., 2000. Derivation of the parameters of the WAVE model using a deterministic and a stochastic approach. $\mathrm{PhD}$ dissertation, Faculty of Agriculture and Applied Biological Sciences K.U. Leuven, Belgium.

Hodges, T., 1991. Temperature and water stress effects on phenology. In: Hodges, T. (Ed.), Predicting crop phenology. CRC Press, Boca Raton, FL, 7-13.

Hoogenboom, G., Jones, J.W., Porter, C.H., Wilkens, P.W., Boote, K.J., Batchelor, W.D., Hunt, L.A., Tsuji, G.Y., 2003. Decision Support System for Agrotechnology Transfer Version 4.0 University of Hawaii, Honolulu.

Hunt, L.A., Boote, K.J., 1998. Data for model operation, calibration and evaluation. In Tsuji, G.Y., G. Hoogenboom., P.K. Thornton., (Eds.) -Understanding Options for Agricultural Production. Kluwer Academic Publishers, Dordrecht, The Netherlands, 9-39.

Jagtap, S.S., Abamu, F.J., Kling, J.G.,1999. Long-term assessment of nitrogen and variety technologies on attainable maize yields in Nigeria using CERES-Maize. Agricultural Systems 60, 77-86.

Jones, C.A., Kiniry, J.A.,1986. CERES-Maize: A simulation model of maize growth and development. Texas A\&M University Press, College Station, Texas, USA. 194.

Jones, J.W., Hoogenboom, G., Porter, C.H., Boote, K.J., Batchelor, W.D., Hunt, L.A., Wilkens, P.W., Singh, U., Gijsman, A.J., Ritchie, J.T., 2003. The DSSAT cropping system model. European Journal of Agronomy $18,235-265$.

Karthikeyan, R., Balasubramanian, T.N., 2005. Evaluation of DSSAT v3.5 CERES-Maize model for western zone of Tamilnadu. Journal of Agrometeorology 7(2), 190-198.

Keating, B.A., Godwin, D.C., Watiki, J.M., 1991. Optimizing nitrogen inputs in response to climatic risk. In: Climatic Risk in Crop Production:Models and Management for the Semi-arid Tropics and Subtropics, Eds. Muchow, R.C. and others, CAG International, Wallingford, U.K.

Kiniry, J.R., Bonhomme, R., 1991. Predicting maize phenology. In: Hodges, T. (Ed.), Predicting crop phenology. CRC 
Press, Boca Raton FL, 115-131.

Loague, K., Green, R.E., 1991. Statistical and graphical methods for evaluating solute transport models: Overview and application. Journal of Contaminant Hydrology 7, $51-73$.

Monteith, J.L., 1981. Climatic variationand growth of crop. Q.J.R. Meteorological Society 107, 749-774.

Pereira, A.M., de, A.R., Pinho, R.G., Von Paglis, C.M., Pereira, J.L., de, A.R., Altoe, T.F., 2010. Efficiency of the CERES-Maize model in the simulation of corn hybrid performance. [Portuguese] Revista Ceres 57, 486-493.

Reddy, D.R., 1991. Crop-Weather Relationship in rabi maize (Zea mays L.) and testing of CERES-Maize model for the middle Gujarath Agroclimatic zone. PhD dissertation. Gujarat Agricultural University, Anand.

Ritchie, T., Godwin, D.C., 1989. Description of soil water balance.,in: Virnami, S.M., H.L.S. Tandon., G. Alagarswamy (Eds.), Modeling the Growth and Development of Sorghum and Pearl Millet, Research Bulletin 12,92-9066-174-7, International Crops Research Institute for the Semi-Arid Tropics, Andhra Pradesh, India, 14-16.

Saseendran, S.A., Ma, L., Nielsen, D.C., Vigil, M.F., Ahuja, L.R., 2005. Simulating Planting Date Effects on Corn Production Using RZWQM and CERES-Maize Models. Agronomy Journal 97, 58-71.

Shekh, A.M., Rao, B.B.,1996. Crop growth modeling possibilities and limitation: An Indian perspective. In: Abrol, Y.B., Gadgil, S., Pant, G.B. (Eds.), Climate variability and Agriculture, Narosa publishing House, New Delhi. 356-374.

Singh, A.K., Balasuramaniyan, K.K., Baxla, R., Tripathi, A.K., Mishra, P.N., 2010. Validation of CERES-Maize model of growth, yield attributes and yield of kharif maize for NEPZ of eastern U.P. Journal of. Agrometeorology 12(1), 118-120.

Singh, U., 1989. IBSNAT's decision support system for agro technology transfer. In: Modeling the Growth and Development of Sorghum and Pearlmillet. Research bulletin No.12, Eds. Viramani and others, ICRISAT, Patancheru, India.

Wallace, D.H., Yan, W., 1998. Plant breeding and wholesystem crop physiology: Improving adaptation, maturity and yield. CAB International, Wallingford, UK.

Wallach, D., Goffinet, B., 1989. Mean squared error of prediction as a criterion for evaluating and comparing system models. Ecological Modelling 44, 200-306.

Willmott, C.J., 1982. Some comments on the evaluation of model performance. Bulletin American Meteorological Society 63, 1309-1313.

Yang, H.S., Dobermann, A., Lindquist, J.L., Walters, D.T., Arkebauer,T.J., Cassman, K.G., 2004. Hybrid-maize: A maize simulation model that combines two crop modeling approaches. Field Crops Research. 87, 131-154. 